\title{
Household responses to malaria: illness perception, cost implications and treatment- seeking behavior of mothers in Calabar, Nigeria
}

\author{
Susan Etim*, Jude Ogbeche \\ From Challanges in malaria research: Core science and innovation \\ Oxford, UK. 22-24 September 2014
}

\begin{abstract}
Malaria contributes substantially to the poor health situation in sub-Saharan Africa accounting for over 2.5 million deaths annually. About $50 \%$ of malaria cases present as outpatient visits and $20 \%$ as hospital admissions, while $30 \%$ of the suspected malaria cases are managed at home using traditional remedies and drugs bought from the local chemist. Malaria, as a serious public health problem, has severe consequences on people of all ages with the greatest burden on the world's poorest communities by affecting productivity and household income. Vulnerability to the consequences of malaria has a lot to do with problems of poverty, access to and cost of treatment and prevention. These are strongly correlated with household income and socio-economic status. There is limited information on the household cost implications and treatmentseeking behavior especially among the urban poor. There is also a need for a better understanding of the malaria infection and disease process to guide the design of effective policies and tools, acceptable and affordable to the people in an attempt the reduce the malaria problem. This paper will examine and determine the factors that influence the perception of malaria, cost implications for treatment and treatment-seeking behavior and preventive measures among the urban poor mothers in Calabar, Nigeria.
\end{abstract}

Published: 22 September 2014

doi:10.1186/1475-2875-13-S1-P102

Cite this article as: Etim and Ogbeche: Household responses to malaria: illness perception, cost implications and treatment-seeking behavior of mothers in Calabar, Nigeria. Malaria Journal 2014 13(Suppl 1):P102.
Submit your next manuscript to BioMed Central and take full advantage of:

- Convenient online submission

- Thorough peer review

- No space constraints or color figure charges

- Immediate publication on acceptance

- Inclusion in PubMed, CAS, Scopus and Google Scholar

- Research which is freely available for redistribution
() Biomed Central

University of Calabar, Calabar, Nigeria 